\title{
Climatic OSCILlations MODUlating THE LATE HOLOCENE FLUVIAL DisCHARGE AND TERRIGENOUS MATERIAL SUPPLY FROM THE RÍO DE LA PLATA INTO THE SOUTHWESTERN ATLANTIC OCEAN
}

\section{Laura Perez ${ }^{*}$, Carolina Crisci ${ }^{1}$, Till Jens Jörg Hanebuth ${ }^{2}$, Hendrik Lantzsch ${ }^{3}$, Gonzalo Perera ${ }^{1}$, MAURICIO RODRÍGUEZ ${ }^{1}$, ANDRES PÉREZ ${ }^{1}$, LAURA FORNARO ${ }^{1}$ AND FELIPE GARCÍA-RODRÍGUEZ ${ }^{1,4}$}

\section{Centro Universitario Regional del Este, CURE-Rocha, Uruguay}

2 Department of Coastal and Marine Systems Sciences, Coastal Carolina University, U.S.A.

3 MARUM - Center for Marine Environmental Sciences and Faculty of Geosci ences, University of Bremen, Leobener Straße, 28359 Bremen, Germany

4 Universidade Federal do Rio Grande, Instituto de Oceanografia, Programa de Pós-Graduação em Oceanografia Física, Química e Geológica, Brazil

*Corresponding author, lp3_3@hotmail.com

Received on 28 August 2018

Received in revised form on 28 November 2018

Accepted on 2 December 2018

Editor: Leticia Burone, Universidad de la República, Uruguai
Citation:

Perez, L., Crisci, C., Hanebuth, T.J.J. Lantzsch, H., Perera, G., Rodríguez, M., Andres Pérez, A., Fornaro, L., García-Rodríguez, F., 2018. Climatic oscillations modulating the Late Holocene fluvial discharge and terrigenous material supply from the Río de la Plata into the Southwestern Atlantic Ocean. Journal of Sedimentary Environments, 3 (4): 205-219.

\section{Abstract}

The Río de la Plata estuary (RdlP) and adjacent continental shelf exhibit complex hydrological processes as a result of a highly variable fluvial discharge and associated terrigenous supply, which are primarily controlled by regional climatic forcing in interaction with the oceanographic system. Previous hydrological studies indicate that Little Ice Age and Medieval Climate Anomaly resulted in increased/decreased river runoff due to an enhanced/weakened precipitation regime. This study aims to analyze the cyclicity in the runoffrelated continental supply and the associated climatic oscillation behind it over the past 1,000 cal yr BP. To achieve this, we used a 10 -m-long sediment core retrieved from the RdlP mud depocenter, which exhibits an extremely high and fairly constant linear sedimentation rate of $1.1 \mathrm{~cm} \mathrm{yr}^{-1}$. We performed continuous $1-\mathrm{cm}$ XRF element intensity scans and performed time series analysis on $\mathrm{Fe} / \mathrm{K}, \mathrm{Ti} / \mathrm{Al}, \mathrm{Fe} / \mathrm{Ca}$, $\mathrm{Ti} / \mathrm{Ca}$ and $\mathrm{Si} / \mathrm{Al}$ ratios, considered as regional proxies for inferring fluvial supply. The most significant cyclicities occur at $215,192,115,100,49,47,37,35$, and $2.5-8$ yrs recurrence times. The long-term cyclicity is persistent throughout the

\section{Introduction}

Climate variability exerts a direct influence on regional precipitation and continental freshwater supply (Barreiro, whole record for all ratios, and it is probably related to solar forcing, i.e., the $200 \mathrm{yr}$ Vries/Suess cycle, which determines the activity of the South American Monsoon System activity. The shorter climate-related cyclicities $(<100 \mathrm{yr})$ are probably related to the Atlantic Multidecadal Oscillation, the Pacific Decadal Oscillation and the El Niño Southern Oscillation climatic modes, and were registered only for $\mathrm{Ti} / \mathrm{Al}, \mathrm{Fe} / \mathrm{K}$ and $\mathrm{Si} / \mathrm{Al}$ ratios. We further identified an intensification of such shorter climate-related cyclicities over the past $500 \mathrm{yr}$ BP. This study provides new evidence that both tropical Pacific and Atlantic SSTs and solar forcing are the main drivers of changes in rainfall over Southeastern South America on interannual to decadal, multidecadal and centennial scales, and thus modulates the RdlP river discharge.

Keywords: Climatic variability. Spectral analyses. XRF element ratios. Mud depocenter. Continental shelf.

2010; García-Rodríguez et al., 2014, Lüning et al., 2018), on oceanographic processes, and also on sediment transport, resuspension and deposition from the continent to the continental shelf (Lantzsch et al., 2014; Marrero et al., 2014; 
Briceño-Zuluaga et al., 2016; Perez et al., 2016). Large estuaries are responsible for most of the terrigenous material supply into the continental margins, and the associated sediment transport processes mobilize terrigenous chemical elements to the coastal zone and continental margins (Depetris, 1968; Bianchi et al., 2007; García-Rodríguez et al., 2014).

In this sense, the chemical elements $\mathrm{Ti}, \mathrm{Fe}$ and $\mathrm{Al}$ are mainly related to aluminosilicates and namely clay minerals as weathering products from the continent (Goldberg and Arrhenius, 1958; Jansen et al., 1998; Yarincik et al., 2000). Therefore, such elements reflect the terrigenous contribution in coastal and offshore sediments (Martins et al., 2007; Burone et al., 2013). The chemical element $\mathrm{K}$ in marine sediments is associated with terrigenous material (Goldberg and Arrhenius, 1958). This chemical element is relatively abundant in arid regions where chemical weathering rates are usually low (Govin et al., 2012). Si is an important nutrient in the oceans as it is a basic component of the skeletons of diatoms, radiolarians, silicoflagellates and sponges (DeMaster, 2002; Libes, 2009). Thus, temporal and spatial variability in the annual cycles of $\mathrm{Si}$ availability in estuaries and coastal areas depend on both river supply and biological production (Bianchi, 2007). In contrast, Ca mainly reflects the marine biogenic carbonate content in the sediment, and is thus associated with local marine productivity (Haug et al., 2001; Salazar et al., 2004; GonzálezMora and Sierro, 2007).

Govin et al. (2012) assessed the potential use of Ti/Ca, $\mathrm{Fe} / \mathrm{Ca}, \mathrm{Ti} / \mathrm{Al}, \mathrm{Fe} / \mathrm{K}$ and $\mathrm{Si} / \mathrm{Al}$ element ratios for Southwestern Atlantic Ocean (SWAO) sediments, to reconstruct different terrestrial past climate regimes. These authors demonstrated that $\mathrm{Ti} / \mathrm{Ca}$ and $\mathrm{Fe} / \mathrm{Ca}$ resemble the terrigenous supply versus the marine influence, as most of the $\mathrm{Ca}$ corresponded to carbonates, related to a marine origin. Furthermore, the $\mathrm{Ti} / \mathrm{Al}$ ratio is appropriate to infer the variability in the input of aeolian versus fluvial terrigenous material, in areas of dust deposition. Also, the $\mathrm{Fe} / \mathrm{K}$ and $\mathrm{Si} / \mathrm{Al}$ are suitable to reconstruct South American climatic zones, with high values of the $\mathrm{Fe}$ and $\mathrm{Al}$, registered in highly weathered tropical areas, and high values of $\mathrm{K}$ and $\mathrm{Si}$, in slightly weathered drier regions, and thus are both proxies of the continental runoff (Govin et al., 2012).

Seager et al. (2010) determined that the variability in sea surface temperature (SST) in both the tropical Pacific and Atlantic Oceans cause most of the Southeastern South American (SESA) temporal precipitation changes. These fluctuations account for most of the interannual to multidecadal variability, with SST in the tropical Pacific dominating at interannual timescales, and those of the tropical Atlantic, dominating at long-term scales (Seager et al., 2010). The interannual variability (i.e., 2-8 yrs. cycles) is related to El Niño Southern Oscillation (ENSO; Depetris and Pasquini, 2007b; Garreaud et al., 2009). The decadal and multidecadal climatic variability in SESA mainly results from two competing climatic modes: the Pacific Decadal Oscillation (PDO) with 30 yr. cycles (Garreaud et al., 2009) and the Atlantic Multidecadal Oscillation (AMO) with $64 \mathrm{yr}$. cycles (Delworth and Mann, 2000).

In the Río de la Plata (RdlP) watershed, the seasonal variability in rainfall is mainly linked to a latitudinal migration of the Intertropical Confluence Zone (ITCZ), an equatorial band of convective activity that migrates northwards in winter, and southwards in summer forming the central element of the South American Monsoon System (SAMS; Zhou and Lau, 1998). During the mature phase of SAMS in summer, intensive convective activity is observed (Fig. 1), associated with an enhancement of the equatorial North Atlantic trade winds, a buildup of strong Northwesterlies along the eastern side of the tropical Andes, and a migration of the South Atlantic Convergence Zone (SACZ) towards its southernmost position (Zhou and Lau, 1998). The SACZ is related to a convective band that extends from the Amazonas Basin to the SWAO (Carvalho et al., 2004; Garcia and Kayano, 2010). Hence, SAMS activity is strongest during austral summer, and SACZ leads to an increase in rainfall over the RdlP watershed (Fig. 1; Robertson and Mechoso, 2000; Chiessi et al., 2009). The opposite pattern is commonly observed during austral winter when SAMS activity is weakest (Fig. 1; Carvalho et al., 2004; Chiessi et al., 2009).

There is significant evidence on the climatic changes occurred during the late Holocene: i.e., the Medieval Climate Anomaly (MCA; AD 800-1300) and the Little Ice Age (LIA; AD 1400-1800) in SESA. Both MCA and LIA exerted an influence on the regional rainfall pattern, with distinct regional differences (Cioccale, 1999; Iriondo, 1999; Meyer and Wagner, 2009; Moy et al., 2009; Piovano et al., 2009; Bird et al., 2011; del Puerto et al., 2011, 2013; Vuille et al., 2012; Apaéstegui et al., 2014; Salvatteci et al., 2014; Perez et al., 2016). Several studies reported a decrease in SAMS activity during MCA and strengthening of SAMS during LIA when compared to pre-MCA times (Fig. 2; Bird et al., 2011; Vuille et al., 2012; Apaéstegui et al., 2014; Salvatteci et al., 2014). Such studies demonstrated that SAMS is sensitive to the latitudinal displacement of the ITCZ, as a response to temperature changes in the northern hemisphere, particularly over the North Atlantic Ocean (Bird et al., 2011). Thus, SAMS variability appears to be closely related to AMO (Chiessi et al., 2009; Apaéstegui et al. 2014). The strengthening/weakening of SAMS during the LIA/MCA led to an increase/decrease in rainfall over the RdlP watershed, with a concomitant increase/decrease in continental freshwater supply to the adjacent SWAO inner continental shelf (Fig. 2; Perez et al., 2016).

To our knowledge, high-resolution studies dealing with climatic oscillations and the associated changes in RdlP fluvial supply to the inner SESA shelf have not yet been undertaken. This study aims to address the late Holocene interannual, decadal, multidecadal and centennial cyclicities of RdlP fluvial discharge and to relate such variability to the 
particular climatic oscillation modes. We analyzed a continuous dataset of high-resolution XRF element ratios using time series analyses to determine the related ciclicity in continental freshwater supply. The additional combination with biogenic Si data allows discriminating between the particular biogenic and terrigenous Si contribution to the sedimentary record. The results significantly help to understand the long-term paleoenvironmental processes in highly dynamic shelf systems, under the regime of strongly coupled climatic-hydrologic-oceanographic interactions.

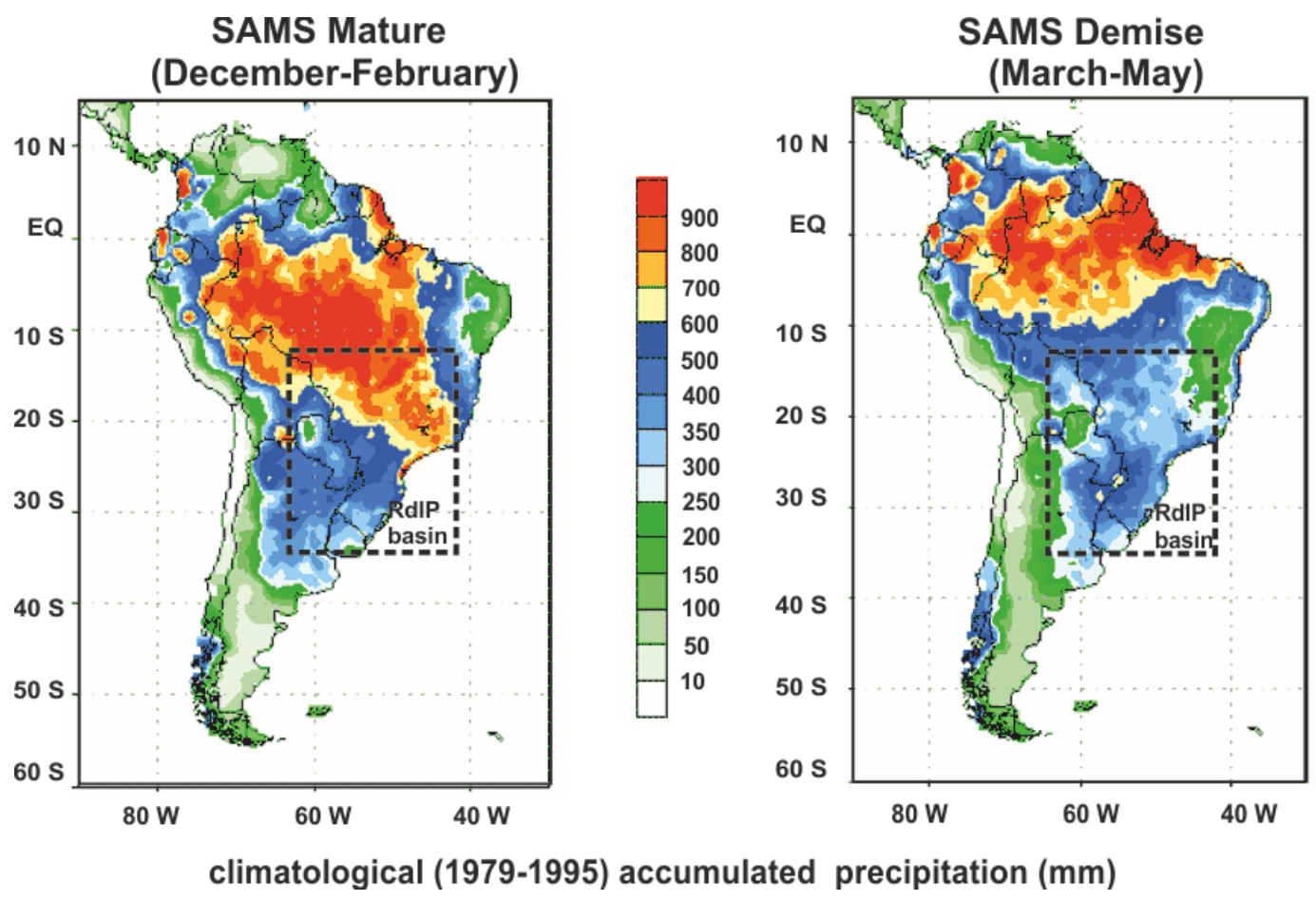

Fig. 1. Seasonal phases (mature and demise) of SAMS and the resulting seasonal precipitation pattern over the RdlP drainage basin (black dotted box). Source: http://www.cpc.ncep.noaa.gov/products/Global_Monsoons/American_Monsoons/SAMS-Phases/

\subsection{Study area}

The RdlP forms through the confluence of the Paraná and Uruguay Rivers and drains into the SWAO as the second largest fluvial system in South America, only exceeded by the Amazon River, at North Brazil (Acha et al., 2003). The watershed covers 20\% of the continent (Acha et al., 2004, 2008). The Paraná River is the largest affluent of the RdlP accounting for $73 \%$ of its water discharge (Depetris and Paquini, 2007a). The RdlP exhibits maximum water discharge during summer, which, together with a dominance of NE winds, displaces the RdlP plume in the offshore direction. In winter, the river discharge decreases, coinciding with a dominance of SW winds that push the RdlP river plume northward and against the coast (Depetris and Paquini, 2007a; Piola et al., 2008). Most of the RdlP freshwater are supplied by the tropical upper Paraná drainage basin, but the total suspended sediment load is mainly supplied by the arid, mountainous and mostly sedimentary upper Bermejo River drainage basin (Depetris et al., 2003). A total of $129 \times 10^{6}$ metric tons of suspended sediments is transported from the Paraná River to the SWAO (Depetris and Giffin, 1968).
The oceanographic system, i.e. the RdlP estuary and adjacent continental shelf, displays a pronounced salinity gradient due to the freshwater supply from the RdlP system, and, to a less extent, from the slightly northward located Patos Lagoon (Acha et al., 2004; Möller et al., 2008; Piola et al., 2008). Below $50 \mathrm{~m}$ water depth, oceanographic fronts and mixing processes of water masses of different salinity, nutrient concentration, and temperature are observed as a consequence of the highly energetic confluence of the shelf branches of Brazil and Malvinas Currents. An oceanographic shelf front extends across the outer shelf, i.e., the subtropical shelf front (Piola et al., 2005). Thus, the interaction of the RdlP and the SWAO forms a complex and dynamic system (Calliari et al., 2009).

The Uruguayan inner shelf hosts a high accumulation mud depocenter (Martins and Urien, 2004; Lantzsch et al., 2014; Perez et al., 2016). The depocenter forms below the $50 \mathrm{~m}$ isobath, inside the RdlP paleo-valley (promoting the deposition and avoiding the resuspension from strong shelf currents), which incised during the lowered sea level associated with the wide, Last Glacial Maximum shelf exposure (Masello and Menafra, 1998; Martins et al., 2003; Lantzsch et al., 2014). 


\section{Materials and Methods}

A 1028-cm long gravity core (GeoB13813-4) was retrieved from the RdlP mud depocenter (34 $44.22^{\prime}$ S, $53^{\circ} 33.27^{\prime} \mathrm{W} ; 57 \mathrm{~m}$ water depth) during the research cruise M78/3a with the German research vessel Meteor in May 2009 (Krastel et al., 2012; Fig. 3a). During this expedition, subbottom echosounder profiling with the shipboard PARASOUND P70 system $(4 \mathrm{kHz}$ secondary parametric signal) showed an elongated depression on the seafloor corresponding to the RdlP paleo-valley, which is filled with a differentiated succession of acoustic facies (Fig. 3b; Krastel et al., 2012; Lantzsch et al., 2014).
RESEARCH PAPER

\subsection{Age-depth model}

Six bivalve shells, evenly distributed over the core and preserved in life position, were collected for radiocarbon dating (Fig. 3c; Lantzsch et al., 2014; Perez et al., 2016). The samples were analyzed using AMS- ${ }^{14} \mathrm{C}$ (accelerated mass spectrometry) at the Poznan Radiocarbon Laboratory (Poland), (Tab. 1). The raw radiocarbon dates were calibrated using the calibration curve Marine13 (Reimer et al., 2013). The standard reservoir age of $324 \pm 30 \mathrm{yr}$ was applied during calibration data (southeastern Brazil; Alves et al., 2016). The age-depth model was developed with the Bacon software (v. 2.2; Blaauw and Christen, 2011; Tab. 1).

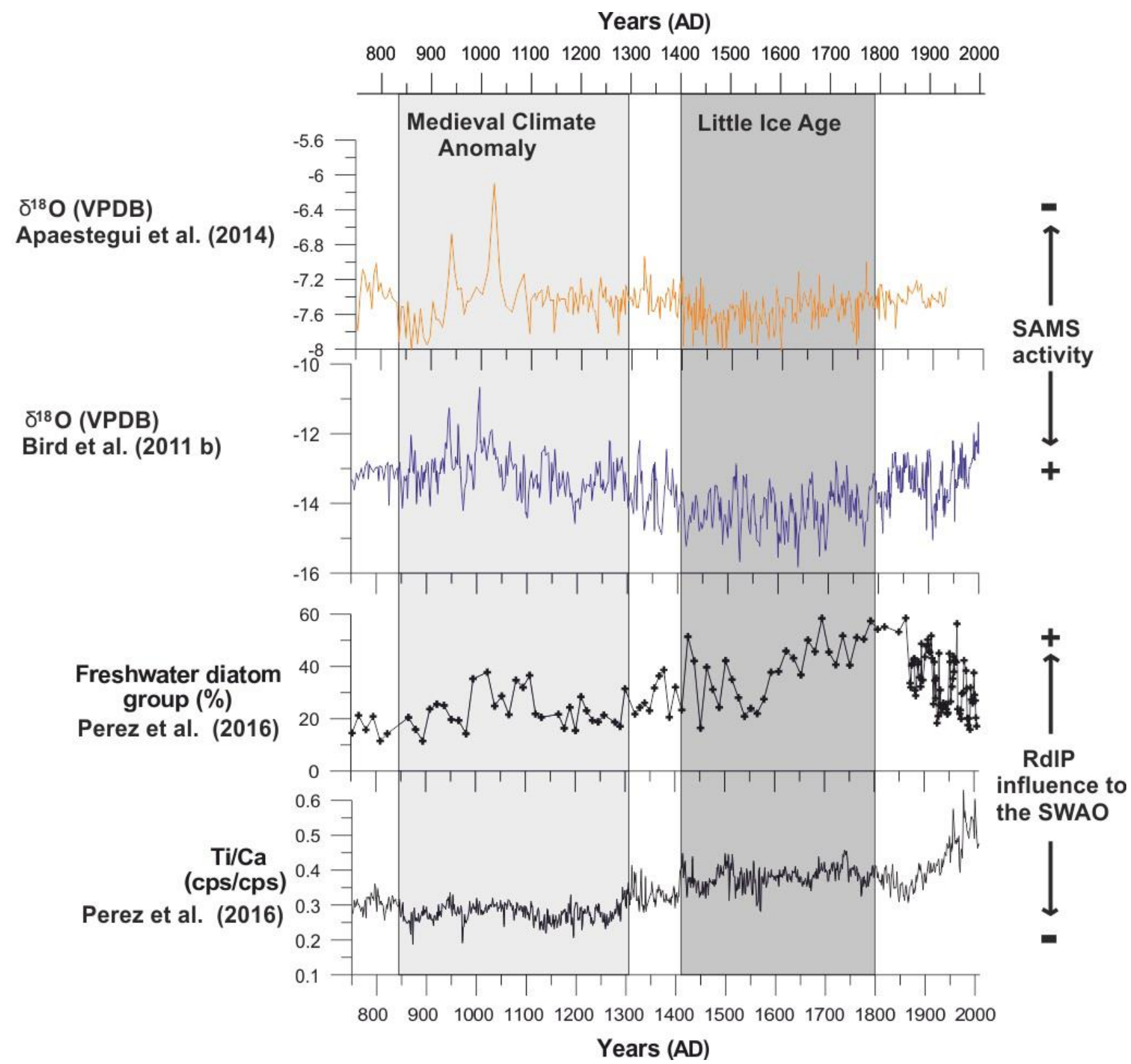

Fig. 2. Comparisons between late Holocene SESA records: SAMS activity changes (Bird et al., 2011; Apaéstegui et al., 2014), and the RdlP freshwater continental supply (Perez et al., 2016), related to the MCA and LIA. Modified from Perez et al. (2016). 


\subsection{X-ray fluorescence sediment core scanning}

Relative intensity distributions of major chemical elements (measured as counts per second, cps) were obtained by XRF sediment core scanning (AVAATECH core scanner at MARUM, University of Bremen) at $1 \mathrm{~cm}$ resolution. To remove the dilution effects, element ratios were plotted following the approach described by Weltje and Tjallingii (2008).

In the present study, we re-assessed $\mathrm{Fe} / \mathrm{K}, \mathrm{Ti} / \mathrm{Al}$, $\mathrm{Fe} / \mathrm{Ca}$ and $\mathrm{Ti} / \mathrm{Ca}$ as regional proxies for cyclicity in continental runoff and fluvial supply to the inner Uruguayan continental shelf, as previously used in Perez et al. (2016). Also, we particularly tested the use of $\mathrm{Si} / \mathrm{Al}$ as a proxy for the reconstruction of marine primary productivity.

\subsection{Fourier transform infrared spectroscopy (FTIR)}

FTIR analysis was performed for the estimation of biogenic silica $(\mathrm{BSi})$ content. Sub-samples were taken every $3 \mathrm{~cm}$ throughout the whole sediment core, except for the upper $100 \mathrm{~cm}$ where the material was sampled every $1 \mathrm{~cm}$. The samples were dried at $100{ }^{\circ} \mathrm{C}$ and ground with an agate mortar and a pestle. An aliquot of $0.015 \mathrm{~g}$ of the sample material was mixed with $0.15 \mathrm{~g}$ of potassium bromide $(\mathrm{KBr}$, which was dried at $105^{\circ} \mathrm{C}$ for $2 \mathrm{~h}$ before use and then placed in a desiccator overnight). The mixed powder was pressed using a 10-ton hydraulic press to generate a transparent pellet, which was stored in a desiccator for a few hours before analysis. A pure $\mathrm{KBr}$ pellet was analyzed as background blank before sample analysis.

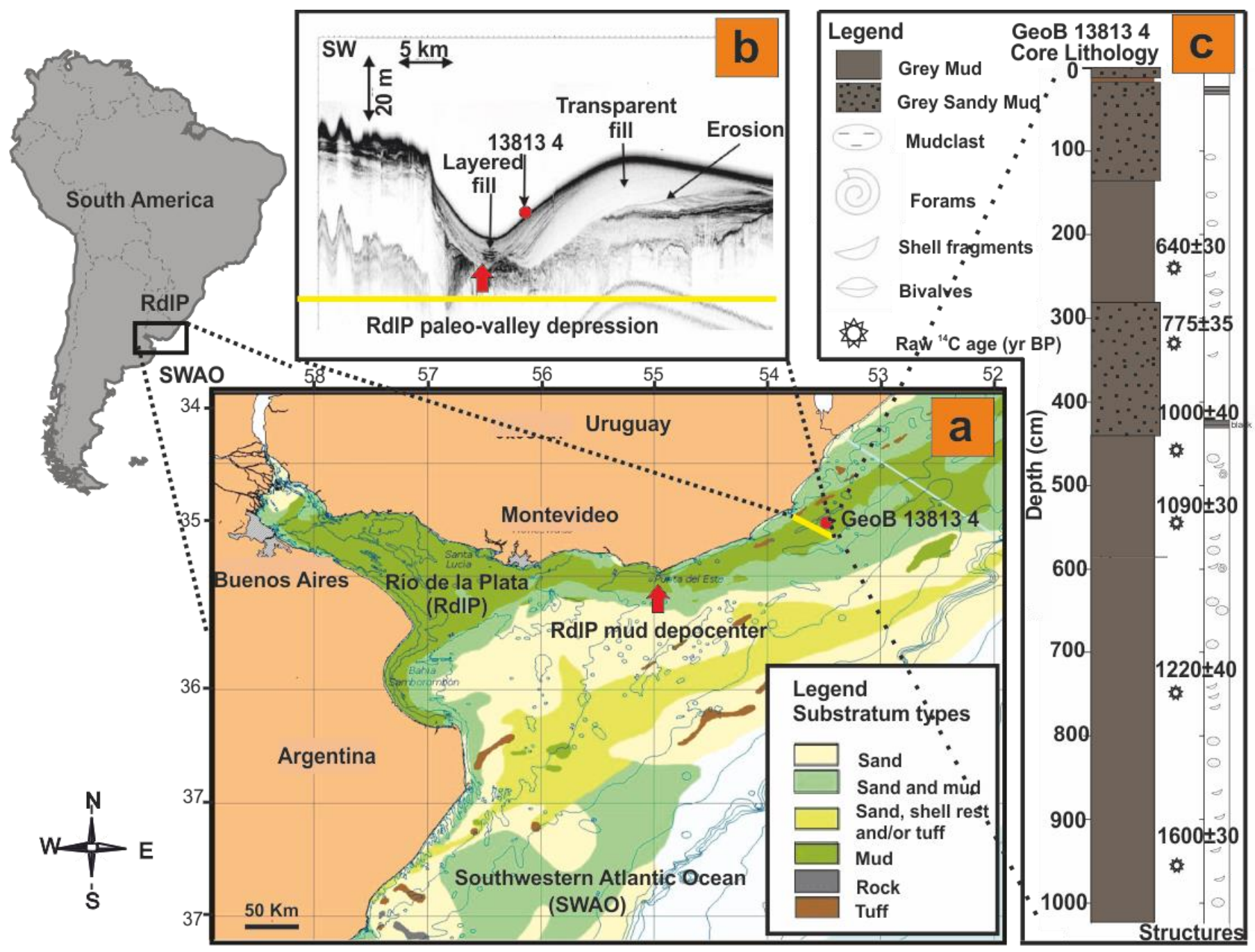

Fig. 3. (a) Study area. The red circle indicates the location of sediment Core GeoB13813-4 retrieved from the inner-shelf mud depocenter off the Uruguayan coast (map modified from Freplata, 2004). (b) PARASOUND sub-bottom echosounder profile showing the stratified mud depocenter inside the RdlP paleo-valley and its sedimentary filling succession (from Lantzsch et al., 2014). (c) GeoB13813-4 core lithology (from Krastel et al., 2012). Stars on the right of the sediment core indicate the depth of radiocarbon ages. The red arrow indicates the RdIP mud depocenter and yellow line corresponds to the cross-section sub-bottom profile. Extracted from Perez et al. (2016). 
A Frontier FTIR spectrometer (Perkin Elmer, USA) was utilized using the $\mathrm{KBr}$ technique (Petrovskii et al., 2016). The instrument operated at a range of wavelengths between 400 and $4000 \mathrm{~cm}^{-1}$ and in the absorbance mode. Twenty scans were averaged at a resolution of $2 \mathrm{~cm}^{-1}$. Spectra were stored and analyzed using the Perkin Elmer spectrum software version 10.03.06.0100. Data treatment was performed using the Origin Pro software (OriginLab, Northampton, MA). FTIR raw data were smoothed using the Saviztky-Golay algorithm with a second-order polynomial and 7 points window. The baseline was carefully determined and subtracted afterward. Data were normalized to the highest peak at $1030 \mathrm{~cm}^{-1}$. Considering that the band at $800 \mathrm{~cm}^{-1}$ is the most appropriate for estimation of BSi content (Petrovskii et al., 2016), we selected the region of $830-660 \mathrm{~cm}^{-1}$ for the partial least squares (PLS) regression (Lindberg et al., 1983; Wold et al., 2001). In order to perform PLS with full cross-validation, a calibration model was constructed using pure diatomaceous powder (Sigma Aldrich) as a BSi standard signal. A synthetic sediment mixture was prepared by adding BSi in consecutive steps to a reference sediment sample, which was previously screened to ensure a low content of BSi. Such a progressivelyincreasing mixture of a sediment sample with diatomaceous powder was thoroughly homogenized in a mortar and subsequently analyzed by FTIR (Meyer-Jacob et al., 2014). The optimum number of terms in the PLS calibration model was selected by minimizing the standard error of crossvalidation.

\subsection{Statistical Analyses}

The continuous time series of element ratios were analyzed with the PAST software (Hammer et al., 2001). First, we performed a spectral analysis on the element ratio series $(\mathrm{Fe} / \mathrm{K}, \mathrm{Ti} / \mathrm{Al}, \mathrm{Fe} / \mathrm{Ca}$, Ti/ $\mathrm{Ca}$ and $\mathrm{Si} / \mathrm{Al})$ following the REDFIT procedure (Schulz and Mudelsee, 2002). REDFIT allows direct processing of unevenly spaced time series, by fitting a first-order autoregressive (AR1) process, characteristic of many climatic processes (Schulz and Mudelsee, 2002). With the REDFIT procedure, the interpolation in the time domain and its inevitable bias can be avoided (Schulz and Mudelsee, 2002). The estimated AR1 model is transformed from the time domain into the
RESEARCH PAPER

frequency domain. The spectrum of the irregularly spaced time series is determined without the need for interpolation using the Lomb-Scargle Fourier transform (Lomb, 1976; Scargle, 1982, 1989). When performing the spectral analysis with REDFIT, we considered the Welch overlapped segment averaging estimator (Welch, 1967) by dividing the time series into five sections with $50 \%$ overlap, and by fitting within each segment, the Lomb-Scargle periodograms considering a Welch window. The resulting periodograms were averaged to obtain the final estimate. To detect significant peaks, the spectrum of a reference red noise was calculated within a $95 \%$ confidence interval assuming a $\chi^{2}$ distribution, (Schulz and Mudelsee, 2002). Peaks exceeding the upper limit of the confidence interval were considered as significant (Schulz and Mudelsee, 2002). The individual periods of the significant peaks were calculated using the equation: $1 /$ peak frequency.

This spectral analysis indicates stationary periodicities, which means they do not change dramatically in either amplitude or frequency through time. In many cases, however, non-stationary periodicities are of interest as well (Hammer, 2010). Morlet wavelet analysis is a suitable tool for analyzing these localized variations of power in a time series. By decomposing a time series into time-frequency space, it is possible to determine both dominant modes of variability as well as mode variability with time (Torrence and Compo, 1998). However, the Morelet wavelet analyses do not allow direct processing of unevenly spaced time series but constant times. Thus, based on the striking linear trend observed in the age-depth model and the homogeneous lithology throughout the whole sediment core GeoB138134, we assumed a mean linear constant net sediment deposition rate of $1.1 \mathrm{~cm} \mathrm{yr}^{-1}$ for wavelet analyses. Based on a mean historical sedimentation rate of $1.1 \mathrm{~cm}$ yr. ${ }^{-1}$, each 1 $\mathrm{cm}$ sampling interval was equivalent to a step of $0.9 \mathrm{yr}$.

\section{Results}

The sedimentation rates between dated intervals ranged from 0.8 to $1.3 \mathrm{~cm} \mathrm{yr}^{-1}$, from bottom to top of the sediment core, with fairly constant values of 1.0-1.1 $\mathrm{cm} \mathrm{yr}^{-1}$ from 305 to $705 \mathrm{~cm}$ depth (Tab. 1). The slope of the linear model generated with the weighted average age was of $1.1 \mathrm{~cm} \mathrm{yr}^{-1}$. The base of the core was dated to 908 cal yr BP (Fig. 4).

Tab. 1. Radiocarbon dates as obtained from the Bacon modeling.

\begin{tabular}{|c|c|c|c|c|c|}
\hline $\begin{array}{l}\text { Lab code \# } \\
\quad(\text { Poz-) }\end{array}$ & $\begin{array}{l}\text { Depth } \\
\text { (cm) }\end{array}$ & Material & $\begin{array}{c}\text { Raw }{ }^{14} \mathrm{C} \text { AMS } \\
\text { age }(\mathrm{yr} \mathrm{BP})\end{array}$ & $\begin{array}{c}2 \sigma(95 \%) \text { calibrated age } \\
\text { (cal. yr BP) }\end{array}$ & $\begin{array}{l}\text { Sedimentation } \\
\text { rate }\left(\mathrm{cm} \mathrm{yr}^{-1}\right)\end{array}$ \\
\hline 35198 & 255 & bivalve shells & $640 \pm 30$ & $62.9-211.8$ & 1.3 \\
\hline 47935 & 305 & bivalve shells & $775 \pm 35$ & $102.4-249.7$ & 1.1 \\
\hline 42428 & 447 & bivalve shells & $1000 \pm 40$ & $247.7-388.4$ & 1.0 \\
\hline 35199 & 560 & bivalve shells & $1090 \pm 30$ & $347.5-490.3$ & 1.1 \\
\hline 47937 & 705 & bivalve shells & $1220 \pm 40$ & $484.4-654$ & 1.0 \\
\hline 42429 & 964 & bivalve shells & $1600 \pm 30$ & 786.7-1102 & 0.80 \\
\hline
\end{tabular}



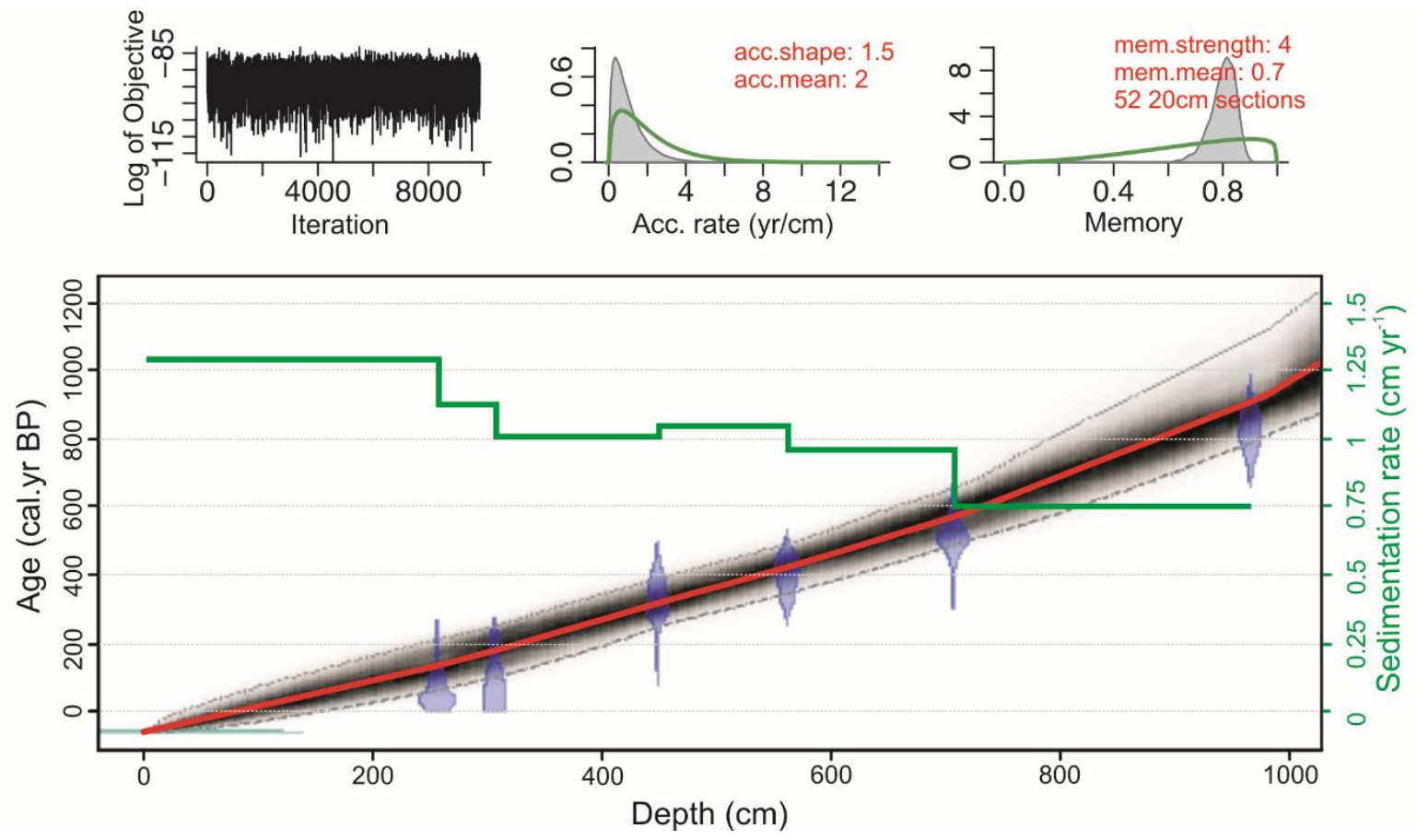

Fig. 4. The age-depth model for Core GeoB13813-4 using the Bacon program. Upper panels depict the Markov Chain Monte Carlo (MCMC) iterations (left), the prior (green curves) and posterior (grey histograms) distributions for the sedimentation rate (middle panel) and memory (right panel). The bottom panel shows the calibrated ${ }^{14} \mathrm{C}$ dates (transparent blue), extraction year of the core (-59 yr. BP, 2009 AD, transparent blue light) and the age-depth model (grey stippled lines indicate the $95 \%$ confidence intervals; the red curve shows the 'best' fit based on the weighted mean age for each depth). Sedimentation rates are shown in green.

The elemental data showed similar vertical distributions throughout the core depth (Fig. 5). In all cases, lowest element levels were observed from $600 \mathrm{~cm}$ to the bottom of the sediment core, while higher and more variable values were detected from $500 \mathrm{~cm}$ to the top. $\mathrm{Ti} / \mathrm{Al}, \mathrm{Fe} / \mathrm{K}$, and $\mathrm{Si} / \mathrm{Al}$ ratios displayed a succession of distinct maximum/minimum peaks from $400 \mathrm{cal}$ yrs BP to present (Fig. 5). All element ratios showed evident increases during the last century, particularly over the past 50 years (Fig. 5).

The spectral analysis of the element ratios performed with the REDFIT method, revealed various significant cycles of multidecadal and centennial variability (i.e. 215, $192,115,100,49,47,37,35$ yrs cycles) but also cycles of shorter duration (i.e. at interannual scales ranging from 2.5 to 8 yrs; Fig. 5). Fe/Ca and Ti/Ca presented a comparable pattern with significant cycles of 215 yrs (Fig. 5). Furthermore, $\mathrm{Ti} / \mathrm{Ca}$ and $\mathrm{Fe} / \mathrm{Ca}$ showed cycles of 2.5-5 yr but this were too close to 0 and they do not appear as significant in the wavelet analysis (Fig. 5). Spectral analysis of Ti/Al displayed significant cycles of 47, 37 and 2.7-8 yr, while $\mathrm{Fe} / \mathrm{K}$ and $\mathrm{Si} / \mathrm{Al}$ displayed similar cycles of 215, 115, 49 and 2.5-5.2 yrs, and 192, 100, 47, 35 and 2.7-3.7 yrs, respectively (Fig. 5). The wavelet analyses of all five element ratios showed that the 192 and 215 yrs cycles were very robust and persisted throughout the whole sediment core, i.e., over the past 1,000 yr BP (Fig. 5). The 35, 37, 47, 49, 100 and 115 yrs cycles were more significant for the $\mathrm{Ti} / \mathrm{Al}, \mathrm{Fe} / \mathrm{K}$ and $\mathrm{Si} / \mathrm{Al}$ and more pronounced during both the LIA and contemporaneous times than during the MCA (Fig. 5). The interannual 2.5-8 yrs cycle was only significant in the wavelet analysis for $\mathrm{Ti} / \mathrm{Al}$ and $\mathrm{Si} / \mathrm{Al}$ during some periods of time within the last $400 \mathrm{yr}$ BP (Fig. 5).

The FTIR analyses revealed that the biogenic silica did not show a trend comparable to that of the $\mathrm{Si} / \mathrm{Al}$ curve (Fig. 6) and the correlation between $\mathrm{Si} / \mathrm{Al}$ element ratio and biogenic Si was low $\left(\mathrm{r}^{2}=-0.11 ; p<0.05\right)$.

\section{Discussion}

\subsection{Late Holocene RdIP bydroclimatic history}

The XRF element ratios must be interpreted as part of an environmental scenario with a high supply of terrigenous continental sediments (source) deposited in the inner Uruguayan continental shelf (Lantzsch et al., 2014; Perez et al., 2016; Mourelle, this volume). Changes in terrigenous supply are associated with the variability in freshwater discharge to the inner shelf and, therefore, to the variability in rainfall over the RdlP watershed. The geochemical and biological evidences throughout the sediment core $\left(\delta^{13} \mathrm{C}\right.$ and $\mathrm{C} / \mathrm{N}$ values ranging between $-20 \% 0$ and $-18.8 \%$ and 9 and 12 , respectively, and both influence of freshwater and marine salinity-indicative diatom groups and palynomorphs), suggest a mixed fluvio-marine signal within the RdIP mud depocenter (Lantzsch et al., 2014; Perez et al., 2016; 2017; Mourelle, this volume). 
Periodicity (yr)
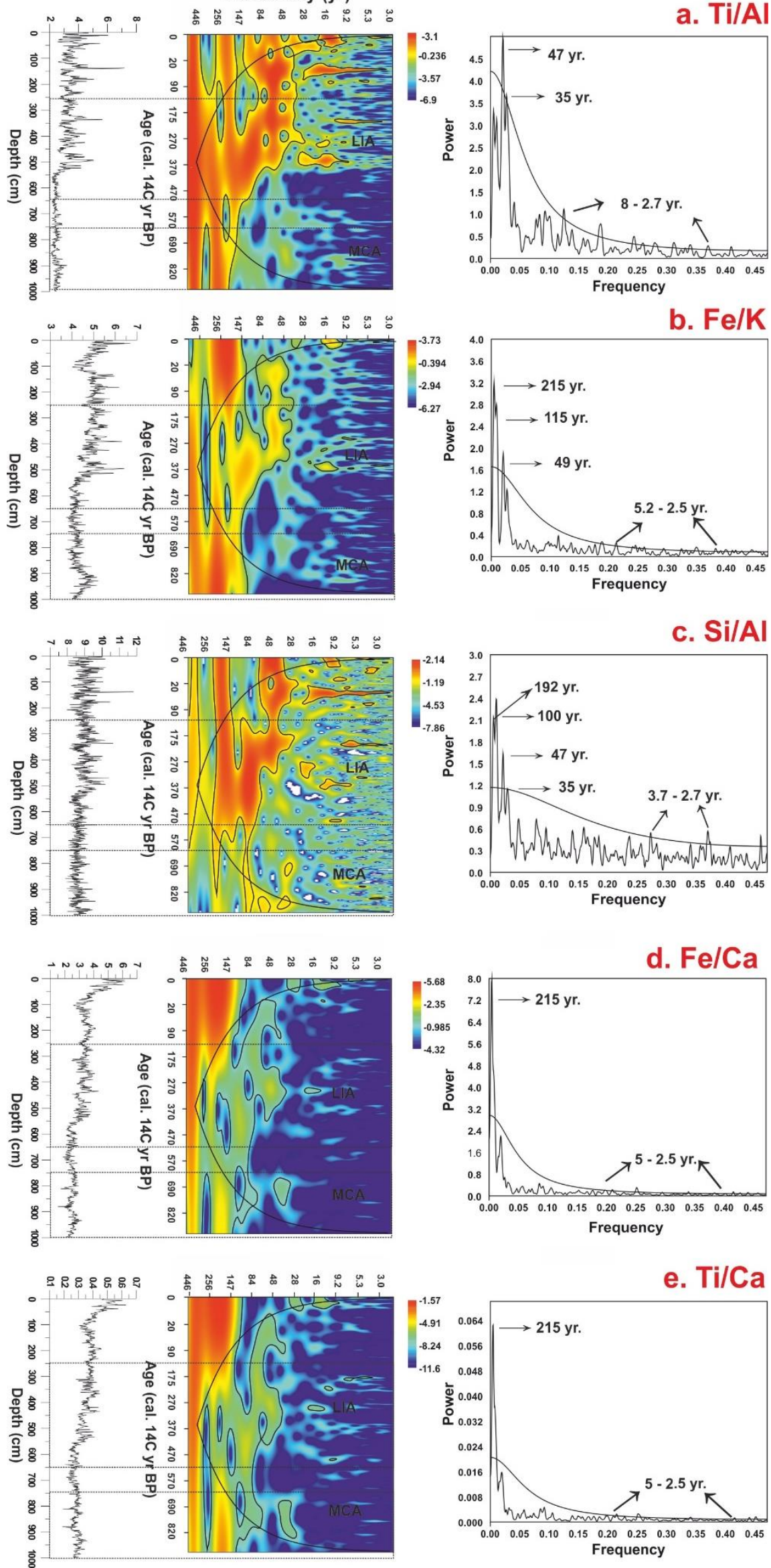

e. $\mathrm{Ti} / \mathrm{Ca}$

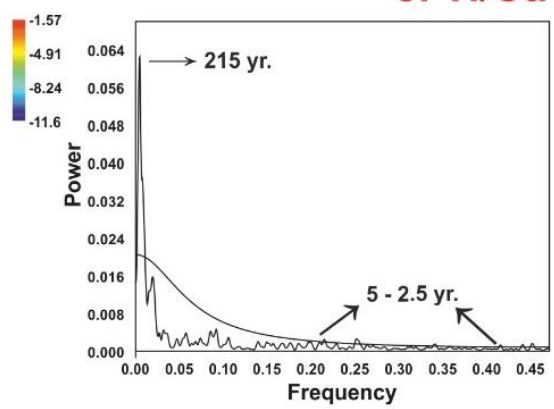


Fig. 5. Time series analysis for Ti/Al, Fe/K, Si/Al, Fe/Ca and Ti/Ca. Element ratio profiles are shown in the left panel, the Lomb periodograms using the REDFIT algorithm are shown to the right. The green line in the periodogram represents the $95 \%$ confidence interval assuming a $\chi^{2}$ distribution. Significant peaks are labeled with their corresponding periods in yr. The results of the wavelet analysis, are shown in the center panel. The abscissa axis corresponds to the depth of the sediment core. The ordinate axis represents the period in yr. Black lines indicate the 95\% significance level and the cone of influence (COI). Inside the COI, the edge effects may become important and the results should be considered with precaution (Torrence and Compo, 1998). The color scale represents the spectral power. Major climatic changes are indicated with dotted lines, i.e., MCA and LIA.

Perez et al. (2016; 2017) identified two main stages, representing two contrasting salinity regimes over the inner continental shelf adjacent to the RdIP, during the last 1000 yr BP. The first, concordant with the MCA, characterized by a reduction in both SAMS and SACZ activities, causing a decrease in the rainfall rate, thus resulting in estuarinemarine conditions predominating over the freshwater plume signal. During the second, i.e., the LIA, a strengthening in both SAMS and SACZ activities, should have led to increased rainfall, and therefore, stronger terrigenous/freshwater supply to the inner shelf.

\subsection{Element ratios and paleoclimate implication}

Numerous studies have used major elements in marine sediments to reconstruct climatic history, but the choice of particular element ratios and the interpretation of such proxies, vary from site to site (Govin et al., 2012). The composition of the terrigenous material that determines the element ratios depends not only on its source (i.e., rock and soil types and their degree of chemical weathering), but are also affected by the input of biogenic opal, calcite, and mafic rock material (Govin et al., 2012). Regarding the sediments influenced by the RdlP river discharge, which are not subject to aeolian input (Mahowald et al., 2006), Govin et al. (2012) observed that $\mathrm{Ti} / \mathrm{Al}, \mathrm{Si} / \mathrm{Al}$ and $\mathrm{Fe} / \mathrm{K}$ ratios resemble the degree of chemical weathering within the drainage basin. This is related to the fact that terrigenous suspended material from the RdIP drainage basin, is mainly related to a mafic rock origin from the arid and mountainous Bermejo River sediments, which are rich in $\mathrm{Ti}, \mathrm{Si}$ and $\mathrm{Fe}$ (Depetris and Griffin 1968; Depetris et al., 2003; Govin et al., 2012). However, biogenic Si can influence the Si/Al ratio (Govin et al., 2012). Hence, to test the use of $\mathrm{Si} / \mathrm{Al}$ as a proxy for productivity in the study area, we measured the biogenic silica content and calculated the correlation between BSi and the $\mathrm{Si} / \mathrm{Al}$ ratio, but we observed a weak negative correlation. Thus, we interpreted the $\mathrm{Si} / \mathrm{Al}$ element ratio, as a proxy for the intensity of continental chemical weathering, also used by Chiessi et al. (2010) for the RdlP watershed. Furthermore, $\mathrm{Ti} / \mathrm{Ca}$ and $\mathrm{Fe} / \mathrm{Ca}$ was highly used as proxy for the $\mathrm{RdlP}$ continental supply versus the SWAO influence (i.e., Chiessi et al., 2009; Mahiques et al., 2009; Govin et al., 2012; Bender et al., 2013; Burone et al., 2013). Therefore, in this study, we propose that $\mathrm{Fe} / \mathrm{K}, \mathrm{Si} / \mathrm{Al}$, and $\mathrm{Ti} / \mathrm{Al}$ truly reflect the terrestrial climatic history over the RdlP drainage basin during the Late Holocene. The variation of such ratios should be related to the changes in the precipitation patterns, which determine the drainage basin chemical weathering, and thus the continental runoff into the adjacent SWAO. In contrast, $\mathrm{Ti} / \mathrm{Ca}$, and $\mathrm{Fe} / \mathrm{Ca}$ do not allow to reliably infer terrestrial climatic conditions as there is a proportion of terrigenous supply relative to the marine calcite production, and thus these element ratios are affected by dilution (Govin et al., 2012). The element ratio cyclicity was determined using time series analysis, and the observed high sedimentation rate, allowed us to infer not only centennial variability for all five ratios, but also further significant cycles of multidecadal and interannual variability (for $\mathrm{Fe} / \mathrm{K}, \mathrm{Si} / \mathrm{Al}$, and $\mathrm{Ti} / \mathrm{Al})$.

\subsection{Centennial and multidecadal cycles}

The wavelet analyses of all five element ratios indicate that the 215 and $192 \mathrm{yr}$ cycles, registered for all periodograms, are very robust, and persistent over the entire record. Such cycles can be related to solar forcing (Patterson et al., 2007; Galloway et al., 2013), e.g., related to the De Vries/Suess 200 yr cycle of solar activity (Novello et al., 2012; Lüdecke et al., 2015). In this sense, such $200 \mathrm{yr}$ Vries/Suess cycle, appears to be the major driver affecting SAMS intensity at centennial time scales, impacting on the northeastern Brazilian rainfalls (Novello et al., 2012, 2016). During warming in the northern hemisphere because of increased solar irradiance, there is a northward shift of the ITCZ with a concomitant weakening of the SAMS (i.e., MCA; Bird et al., 2011; Apaéstegui et al., 2014). Thus, a decreasing RdlP river discharge was inferred during the MCA, while the opposite pattern was inferred during periods of reduced solar irradiance, i.e., LIA (Perez et al., 2016).

The 115, 100, 49 and $47 \mathrm{yr}$ cycles inferred from Ti/Al, $\mathrm{Si} / \mathrm{Al}$, and $\mathrm{Fe} / \mathrm{K}$ element ratios are most probably related to the AMO (Fig. 5; Deser et al., 2010; Ólafsdóttir et al., 2013). Such climatic oscillation cycles were reported for SESA by Chiessi et al. (2009), Seager et al. (2010) and Apaéstegui et al. (2014). AMO is an ongoing series of long-term changes in SST in the North Atlantic Ocean and is considered to be a natural oscillation mode of the Atlantic Ocean's thermohaline circulation (Delworth and Mann, 2000; Deser et al., 2010). AMO exerts an effect on SAMS and SACZ intensity, leading to reduced intensity during positive AMO phases, thus decreasing the precipitations over SESA and vice versa (Chiessi et al., 2009; Apaéstegui et al., 2014). Consequently, a decreased RdlP river flow is expected during 
times of lower precipitations (Tab 2). Furthermore, it was documented that during a North Atlantic cooling (negative phase of AMO) a southward shift of the ITCZ takes place, accompanied by an associated increasing of Southern Ocean mid-latitude surface westerlies (Lee et al., 2011). Therefore, an increase in the RdlP river discharge is expected together with the dominance of SW winds, which pushes the RdlP plume northwards (Piola et al., 2008). Despite the multidecadal cycles are evident in $\mathrm{Ti} / \mathrm{Al}, \mathrm{Si} / \mathrm{Al}$ and $\mathrm{Fe} / \mathrm{K}$ periodograms, the intensity of the cycles of all five element ratios, throughout the time, is higher during the LIA and contemporaneous times comparing with those of the MCA (Fig.5). Such a pattern is particularly distinct in Ti/Al, Si/Al and $\mathrm{Fe} / \mathrm{K}$ wavelet analysis plots, and can be related to the fact that these terrigenous element ratios truly reflect the continental climatic changes over the RdlP drainage basin. On the other hand, $\mathrm{Ti} / \mathrm{Ca}$ and $\mathrm{Fe} / \mathrm{Ca}$ are affected by dilution (Govin et al., 2012). Furthermore, this issue explains the absence of such a multidecadal cyclicity in the $\mathrm{Fe} / \mathrm{Ca}$ and Ti/Ca periodograms.

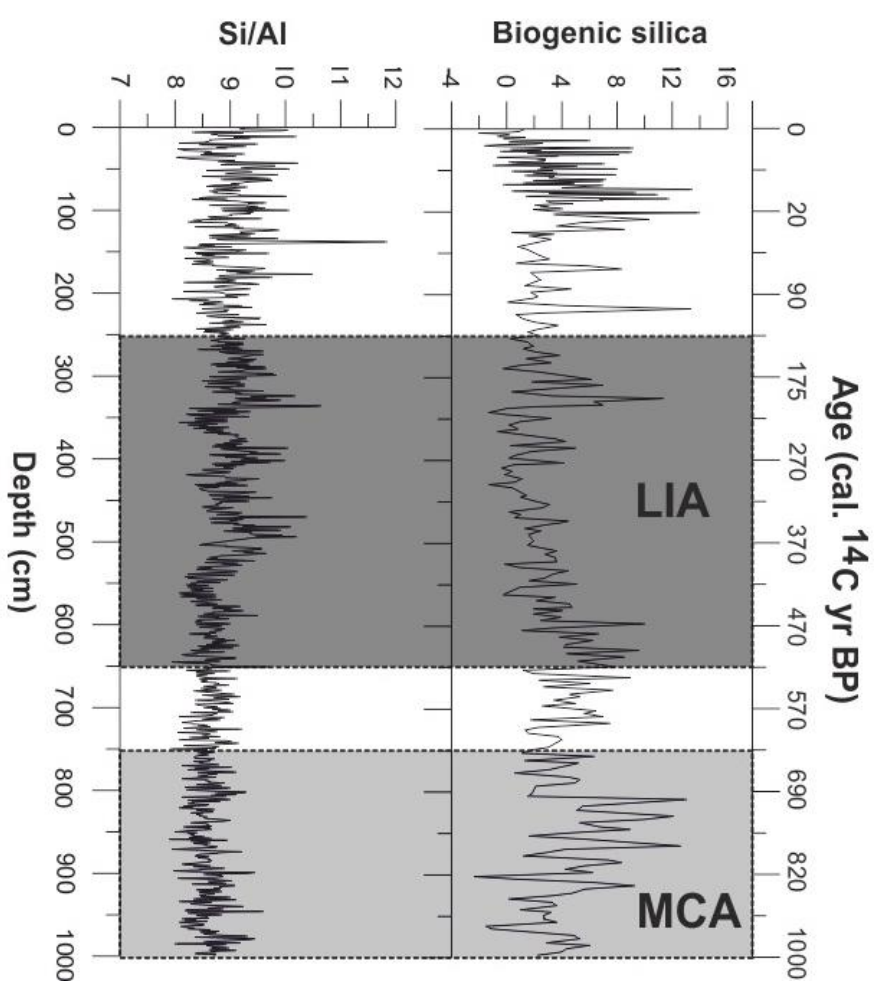

Fig. 6. Variation in $\mathrm{Si} / \mathrm{Al}$ and biogenic silica (\%) in sediment Core GeoB13813-4 for the last 1,000 cal yr BP.

\subsection{Decadal and interannual cycles}

The shorter frequency cycles (2.5-8 yr cycles) registered only for $\mathrm{Ti} / \mathrm{Al}, \mathrm{Fe} / \mathrm{K}$ and $\mathrm{Si} / \mathrm{Al}$ ratios are most probably related to the ENSO mode of variability (Deser et al., 2010). Similar ENSO short oscillation cycles were determined for both Uruguay and Paraná River (Robertson and Mechoso,
1998; Krepper et al., 2003). Robertson and Mechoso (2000) and Seager et al. (2010) demonstrated that El Niño conditions have led to increased river flows of SESA. Furthermore, the significant decadal 35 and $37 \mathrm{yr}$ cycles, registered for $\mathrm{Ti} / \mathrm{Al}$ and $\mathrm{Si} / \mathrm{Al}$ ratios, are most probably associated with PDO (Deser et al., 2010; Fig.5). PDO and ENSO are related to changes in the Pacific SST (Delworth and Mann, 2000; Deser et al., 2010). ENSO is an interannual anomaly from expected SSTs in the equatorial Pacific Ocean, while PDO is described as a decadal El Niño-like pattern of the Pacific Ocean climate variability (Garreaud et al., 2009). PDO is, at the same time, associated with ENSO as both seem to produce similar climatic effects, although their intrinsic mechanisms are not yet fully understood (Garreaud et al., 2009). Such climatic oscillations play an important role in the precipitation variability within the RdlP watershed (Tab 2; Chiessi et al., 2009; Garreaud et al., 2009). It has been suggested that during both warm phases, there is an increasing trend in precipitation over the RdlP watershed, associated to an intensification of the SAMS and higher RdIP discharge, while the opposite trend was inferred for the cold phases (Tab 2; Ciotti et al., 1995; Depetris and Pasquini, 2007 b; Garreaud et al., 2009; Barreiro, 2010; Marrero et al., 2014). Thus, we observed higher values of $\mathrm{Ti} / \mathrm{Al}, \mathrm{Si} / \mathrm{Al}$ and $\mathrm{Fe} / \mathrm{K}$ during LIA which is considered to be an El Niño-like anomaly, while we recorded the opposite pattern during MCA (Pausata et al., 2015).

\subsection{The Atlantic and Pacific teleconnections}

The AMO was shown to modify the characteristics of interannual variability in the Pacific (i.e., ENSO), via atmospheric teleconnection patterns, where changes originating in the Atlantic appear to exert an effect on the base-state properties of the Pacific, by altering the trade wind characteristics (Delworth et al., 2007). Therefore, a warm phase of the AMO leads to a weakening in ENSO variability. In contrast, when the northern hemisphere cooling shifts the ITCZ southwards, it triggers a weakening in trade winds over the western and central equatorial Pacific, which propitiates the development of an El Niño-like anomaly (e.g., during LIA; Pausata et al., 2015). This is the most plausible explanation for our observation of an intense AMO followed by more intense PDO and ENSO during the last $500 \mathrm{yr}$ BP. Thus, we infer an increase in the fluvial discharge and terrigenous material supply during the LIA and contemporaneous time due to an intensification of AMO, PDO and ENSO signal. The reason why we only registered AMO, ENSO and PDO climatic modes of oscillations within the $\mathrm{Ti} / \mathrm{Al}, \mathrm{Fe} / \mathrm{K}$ and $\mathrm{Si} / \mathrm{Al}$ element ratio, is because they truly reflect the terrestrial climatic history over the RdlP drainage, while $\mathrm{Ti} / \mathrm{Ca}$ and $\mathrm{Fe} / \mathrm{Ca}$ are related to marine productivity also modulated by oceanographic processes. This study introduces further evidence that both tropical Pacific and Atlantic SST and solar forcing are the 
main drivers of SESA changes in rainfall at interannualdecadal, multidecadal and centennial scales. Also, the RdlP watershed precipitation strongly depends on such PacificAtlantic interactions (Seager et al., 2010).

\section{Conclusions}

Changes in the XRF element ratios studied from a sediment core retrieved from the RdlP mud depocenter mainly follows the paleoclimatic history of the RdlP drainage basin, but also the paleoceanographic history of the SWAO (related to the marine productivity). In this sense, $\mathrm{Ti} / \mathrm{Al}$, $\mathrm{Fe} / \mathrm{K}$ and $\mathrm{Si} / \mathrm{Al}$, follows the degree of chemical weathering and thus, record the terrestrial climatic history over the RdlP drainage basin during the Late Holocene, mostly related to changes of the precipitation patterns. Furthermore, Ti/Ca, and $\mathrm{Fe} / \mathrm{Ca}$ reflect the continental supply versus the marine biogenic calcite production in the RdlP estuary and the coastal SWAO region and thus is affected by dilution. Thus, $\mathrm{Ti} / \mathrm{Al}, \mathrm{Fe} / \mathrm{K}$ and $\mathrm{Si} / \mathrm{Al}$ were more informative in terms of decipher the climatic oscillation modes affecting the continental input into the Uruguayan inner continental shelf.

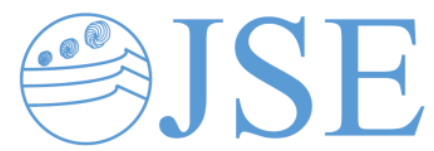

RESEARCH PAPER

This study shows that the terrigenous sediment supply from the RdlP to the continental shelf was strongly controlled by long-term regional climatic cyclicities: i.e., 215 and 192 yrs cycles, most probably related to solar forcing (i.e., the 200 yrs Vries/Suess cycle), as well as by shorter climatic cyclicities ( $<100 \mathrm{yrs})$. The most significant shorter cyclicities occur at $115,100,49,47,37,35$ and 2.5-8 recurrence times, only for $\mathrm{Ti} / \mathrm{Al}, \mathrm{Fe} / \mathrm{K}$ and $\mathrm{Si} / \mathrm{Al}$. Such shorter climate-related cyclicities are most probably related to the AMO, the PDO and the ENSO climatic modes of oscillations.

Furthermore, the variability of these competing climatic modes modulates the latitudinal migration pattern and the regional establishment of ITCZ, SAMS, and SACZ. As a consequence, these climatic modes and their variability determine the regional precipitation patterns and weathering over SESA and the RdlP drainage basin, and thus determine the input of terrigenous material, as inferred from the element ratios of the inner Uruguayan continental shelf sediments. Furthermore, we observed an intensification of the multidecadal, decadal and interannual cycles during the last 500 yr BP.

Tab. 2. Climatic oscillation modes and their relationship to rainfall in the RdlP watershed.

\begin{tabular}{|c|c|c|c|c|c|c|}
\hline \multirow[b]{3}{*}{ Phases } & \multicolumn{6}{|c|}{ Climatic oscillation modes } \\
\hline & \multicolumn{2}{|c|}{ AMO } & \multicolumn{2}{|c|}{ PDO } & \multicolumn{2}{|c|}{ ENSO } \\
\hline & + & - & + & - & + & - \\
\hline $\begin{array}{l}\text { RdlP Watershed } \\
\text { Rainfall }\end{array}$ & Decrease & Increase & Increase & Decrease & Increase & Decrease \\
\hline Reference & $\begin{array}{l}\text { Chiessi et a } \\
\text { Seager et a }\end{array}$ & $\begin{array}{l}\text { 2009); } \\
010)\end{array}$ & Garreaud & 1. $(2009)$ & $\begin{array}{l}\text { Depetris a } \\
\text { al. (2009); }\end{array}$ & $\begin{array}{l}\text { (2007b); Garreaud et } \\
(2010)\end{array}$ \\
\hline
\end{tabular}

\begin{abstract}
Acknowledgment
We acknowledge PEDECIBA (Programa para el Desarrollo de las Ciencias Básicas) Geociencias, ANII (Agencia Nacional de Investigación e Innovación) and DAAD (German Academic Exchange Service). This research used data acquired at the XRF Core Scanner Lab at the MARUM - Center for Marine Environmental Sciences, University of Bremen, Germany. Sample material has been provided by the GeoB core repository at the MARUM. The data reported in this paper are archived in Pangea (www.ángea.de). This article is an outcome of the MARUM SD2 project as part of the DFG 543 Research Center/Excellence Cluster "The Ocean in the Earth System" at the University of Bremen. We would like to express special thanks to the editors and reviewers for their critical comments and suggestions, which improved the manuscript content.
\end{abstract}

\section{References}

Acha, E.M., Mianzan, H.W., Guerrero, R., Carreto, J., Giberto, D., Montoya, N., Carignan, M., 2008. An overview of physical and ecological processes in the Rio de la Plata Estuary. Continental Shelf Research 28, 1579-1588. https://doi.org/10.1016/j.csr.2007.01.031

Acha, E.M., Mianzan, H.W., Guerrero, R.A., Favero, M., Bava, J., 2004. Marine fronts at the continental shelves of austral South America: Physical and ecological processes. Journal of Marine Systems 44, 83-105. https://doi.org/10.1016/j.jmarsys.2003.09.005

Acha, E.M., Mianzan, H.W., Iribarne, O., Gagliardini, D., Lasta, C., Daleo, P., 2003. The role of the Río de la Plata bottom salinity front in accumulating debris. Marine Pollution Bulletin 46, 197-202. https://doi.org/10.1016/S0025-326X(02)00356-9

Alves, E., Macario, K., Souza, R., Pimenta, A., Douka, K., Oliveira, F., Chanca, I., Angulo, R., 2016. Corrigendum to 'Radiocarbon reservoir corrections on the Brazilian coast from prebomb marine shells'. Quaternary Geochronology 31, 1-2. 
Apaéstegui, J., Cruz, F.W., Sifeddine, A., Vuille, M., Espinoza, J. C., Guyot, J.L., Khodri, M., Strikis, N., Santos, R.V., Cheng, H., Edwards, L., Carvalho, E., Santini, W., 2014. Hydroclimate variability of the northwestern Amazon Basin near the Andean foothills of Peru related to the South American Monsoon System during the last 1600 years. Climate of the Past 10, 19671981. https://doi.org/10.5194/cp-10-1967-2014

Barreiro, M., 2010. Influence of ENSO and the South Atlantic Ocean on climate predictability over Southeastern South America. Climate Dynamics 35, 493-1508. https://doi.org/10.1007/S00382-009-0666- 9.

Bender, V.B., Hanebuth, T., Chiesi, C.M., 2013. Holocene shifts of the subtropical shelf front off Southeastern South America controlled by high and low latitude atmospheric forcings. Paleoceanography 28, 1-10. https://doi.org/10.10021palo.20044

Bianchi, T.S. (ed), 2007. Biogeochemistry of estuaries. Oxford University Press, Texas, 700 p.

Bird, B.W., Abbott, M.B., Vuille, M., Rodbell, D.T., Stansella, N.D., Rosenmeiera, M.F., 2011. 2,300-year-long annually resolved record of the South American summer monsoon from the Peruvian Andes. PNAS 108, 8583-8588.

Blaauw, M., Christen, J.A., 2011. Flexible paleoclimate age-depth models using an autoregressive gamma process. Bayesian Analysis 6, 457-474.

Briceño-Zuluaga, F.J., Sifeddine, A., Caquineau, S., Cardich, J., Salvatteci, R., Gutierrez, D., Ortlieb, L., Velazco, F., Boucher, H., Machado, C., 2016. Terrigenous material supply to the Peruvian central continental shelf (Pisco, 14 S) during the last 1000 years: paleoclimatic implications. Climate of the Past 12, 787-798. https://doi.org/10.5194/cp-12-787-2016.

Burone, L., Ortega, L., Franco-Fraguas, P., Mahiques, M., GarcíaRodríguez, F., Venturini, N., Marin, Y., Brugnoli, E., Nagai, R., Muniz, P., Bicego, M., Figueira, R., Salaroli, A., 2013. A multiproxy study between the Río de la Plata and the adjacent South-weastern Atlantic inner shelf to asses the sediment footprint of river vs. marine influence. Continental Shelf Research 55, 141-154. https://doi.org/10.1016/j.csr.2013.01.003

Calliari, D., Brugnoli, E., Ferrari, G., Vizziano, D., 2009. Phytoplankton distribution and production along a wide enviromental gradient in the South-West Atlantic off Uruguay. Hydrobiologia 620, 47-61. https://doi.org/10.1007/s10750008-9614-7.

Carvalho, L.M.V., Jones, C., Liebmann, B., 2004. The South Atlantic Convergence Zone: Intensity, Form, Persistence, and Relationships with Intraseasonal to Interannual Activity and Extreme Rainfall. Journal of Climate 17, 88-108.

Cioccale, M., 1999. Climatic conditions in the central region of Argentina in the last 1000 years. Quaternary International 62, $35-47$.

Ciotti, A.M., Odebrecht, C., Fillmann, G., Moller, O.O., 1995. Freshwater outflow and Subtropical Convergence influence on phytoplankton biomass on the southern Brazilian continental shelf. Continental Shelf Research 15(14), 1737-1756. https://doi.org/10.1016/0278-4343(94)00091-Z

Chiessi, C.M., Mulitza, S., Patzold, J., Wefer, G., 2010. How different proxies record precipitation variability over southeastern South America. PAGES 1st Young Scientists

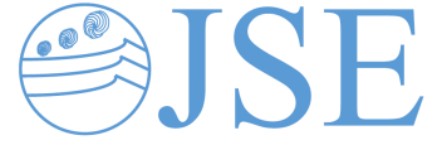

RESEARCH PAPER

Meeting (YSM) - 'Retrospective views on our planet's future' IOP Publishing: Earth and Environmental Science 9, 012007. https://doi:10.1088/1755-1315/9/1/012007.

Chiessi, C.M., Mulitza, S., Patzold, J., Wefer, G., Marengo, J.A., 2009. Possible impact of the Atlantic Multidecadal Oscillation on the South American summer monsoon. Geophysical Research Letters 36, L21707. https://doi.org/10.1029/2009GL039914

DeMaster, D.J., 2002. The accumulation and cycling of biogenic silica in the Southern Ocean: revisting the marine silica budget. Deep-Sea Research II. 46, 3155-3167.

Delworth, T.L., Mann, M.E., 2000. Observed and simulated multidecadal variability in the Northern Hemisphere. Climate Dynamics 16, 661-676. https://doi.org/10.1007/s003820000075

Delworth, T.L., Zhang R., Mann, M.E., 2007. Decadal to Centennial Variability of the Atlantic From Observations and Models. In: Ocean Circulation: Mechanisms and Impacts. Geophysical Monograph Series 173, American Geophysical Union.

Deser, C., Alexander, M.A., Shang-Ping, X., Phillips, A.S., 2010. Sea Surface Temperature Variability: Patterns and Mechanisms. Annual Review of Marine Science 2, 115-43. https://doi.org/10.1146/annurev-marine-120408-151453

del Puerto, L., García-Rodríguez, F., Bracco, R., Castiñeira, C., Blasi, A., Inda, H., Mazzeo, N., Rodríguez, A., 2011. Evolucion climatica holocenica para el sudeste de Uruguay, Analisis multiproxy en testigos de lagunas costeras. In: García-Rodríguez (ed) El Holoceno en la zona costera de Uruguay. Universidad de la Republica (UdelaR), pp. 117-154.

del Puerto, L., Bracco, R., Inda, H., Gutierrez, O., Panario, D., García-Rodríguez, F., 2013. Assessing links between late Holocene climate change and paleolimnological development of Peña Lagoon using opal phytoliths, physical, and geochemical proxies. Quaternary International 287, 89-100. https://doi.org/10.1016/j.quaint.2011.11.026.

Depetris, P.J., Pasquini, A.I., 2007 a. The geochemistry of the Paraná river: an overview. En: Parma M J (eds) Limnology of a subtropical wetland. Springer-Verlag Berlin Heidelberg. pp. 144-174.

Depetris, P.J., Pasquini, A.I., 2007 b. Discharge trends and flow dynamics of southern southamerican rivers draining the southern Atlantic seabord: an overview. Journal of Hydrology 333, 385-399. https://doi.org/10.1016/j.hydrol.2006.09005.

Depetris, P.J., Probst, J.-L., Pasquini, A.I., Gaiero, D.M., 2003. The geochemical characteristics of the Paraná River suspended sediment load: an initial assessment. Hydrol. Process. 17, 12671277. https://doi.org/10.1002/hyp.1283.

Depetris, P.J., Griffin, J.J., 1968. Suspended load in the Río de la Plata drainage basin. Sedimentology. 11 (1-2), 53-60. https://doi.org/10.1111/j.1365-3091.1968.tb00840.x

Freplata, 2004. Análisis Diagnóstico Transfronterizo del Río de la Plata y su Frente Marítimo. Documento Técnico. Proyecto "Protección Ambiental del Río de la Plata y su Frente Marítimo: Prevención y Control de la Contaminación y Restauración de Hábitats". Proyecto PNUD/GEF/RLA/99/G31, 106. 
Galloway, A., Wigston, R.T., Patterson, G.T., Swindles, E., Reinhardt, H.M., Roe, H.M., 2013. Climate change and decadal to centennial-scale periodicities recorded in a late Holocene NE Pacific marine record: Examining the role of solar forcing. Palaeogeography, Palaeoclimatology, Palaeoecology 386, 669689. https://doi.org/10.1016/j.palaeo.2013.06.031

Garcia, S., Kayano, M., 2010. Some evidence on the relationship between the South American monsoon and the Atlantic ITCZ. Theoretical and Applied Climatology 99, 29-38.

García-Rodríguez, F., Brugnoli, E., Muniz, P., Venturini, N., Burone, L., Hutton, M., Rodríguez, M., Pita, A., Kandratavicius, N., Pérez, L., Verocai, J., 2014. Warm phase ENSO events modulate the continental freshwater supply and the trophic state of sediments in a large South American estuary. Marine and Freshwater Research 65(1), 1-11. https://doi.org/10.1071/MF13077

Garreaud, R.D., Vuille, M., Compagnucci, R., Marengo, J., 2009. Present-day South American climate. Palaeogeography, Palaeoclimatology, Palaeoecology 281 (3-4), 180-195. https://doi.org/10.1016/j.palaeo.2007.10.032

Goldberg, E.D., Arrhenius, G.O.S., 1958. Geochemistry of pacific pelagic sediments. Geochim. Cosmochim. Ac. 13, 153-212.

González-Mora, B., Sierro, F.J., 2007. Caracterización geoquímica de las capas ricas en materia orgánica registradas durante el estadio isotópico marino 7 en el Mar de Alborán (Mediterráneo occidental). Geogaceta, 43, 111-114.

Govin, A., Holzwarth, U., Heslop, D., Keeling, L.F., Zabel M., Mulitza, S., Collins, J.A., Chiessi, C.M., 2012. Distribution of major elements in Atlantic surface sediments $\left(36^{\circ} \mathrm{N}-49^{\circ} \mathrm{S}\right)$ : Imprint of terrigenous supply and continental weathering. Geochemistry, Geophysics, Geosystems 13(1),1525-2027. https://doi.org/10.1029/2011GC003785

Hammer, Ø., Harper, D.A.T., Ryan, P.D., 2001. PAST: Paleontological statistics software package for education and data analysis. Palaeontologia Electronica 4(1), 9pp.

Hammer, Ø., 2010. Time series analysis with PAST. Website of the Natural History Museum, University Oslo, 18 pp.

Haug, G.H., Hughen, K.A., Sigman, D.M., Peterson, L.C., Rohl, U., 2001. Southward Migration of the Intertropical Convergence Zone through the Holocene. Science 293, 13041307. https://doi.org/10.1126/science.1059725

Iriondo, M., 1999. Climatic changes in the South American plains: Records of a continent-scale oscillation. Quaternernary International 57/58, 93-112. https://doi.org/10.1016/S10406182(98)00053-6

Jansen, J.H.F., Van der Gaast, S.J., Koster, B., Vaars, A.J., 1998. CORTEX, a shipboard XRF-scanner for element analyses in split sediment cores. Marine Geology 151, 143-153.

Krastel, S., Wefer, G. and cruise participants, 2012. Report and preliminary results of RV METEOR Cruise M78/3. Sediment transport off Uruguay and Argentina: From the shelf to the deep sea. 19.05.2009 - 06.07.2009, Montevideo (Uruguay) Montevideo (Uruguay). Berichte, Fachbereich Geowissenschaften, Universität Bremen, 285, 79 p.

Krepper, C.M., Garcia, O.N., Jones, P.D., 2003. Interannual variability in the Urguay river basin. International Journal of Climatology 23, 103-115. https://doi.org/10.1002/joc.853

Lantzsch, H., Hanebuth, T.J.J., Chiessi, C.M., Schwenk, T., Violante, R., 2014. A high-supply sedimentary system
RESEARCH PAPER

controlled by strong hydrodynamic conditions (the continental margin off the Plata Estuary during the late Quaternary. Quaternary Research 81(2), 339-354. http://dx.doi.org/10.1016/j.yqres.2014.01.003

Lee, S.-Y.H.J., Chiang, K.M., Kathy, S.T., 2011. Southern Ocean wind response to North Atlantic cooling and the rise in atmospheric CO2: Modeling perspective and paleoceanographic implications. Paleoceanography. 26, PA1214. https://doi.org/10.1029/2010PA002004.

Libes, M., 2009. Introduction to marine biogeochemistry, segunda edicion, ELSEVIER, Academic Press, 893 p.

Lindberg, W., Persson, J.-A., Wold, S., 1983. Partial least-squares method for spectrofluorimetric analysis of mixtures of humic acid and lignin sulfonate. Analytical Chemistry 55 (4), 643-648. https://doi.org/10.1021/ac00255a014.

Lomb, N.R., 1976. Least-squares frequency analysis of unequally spaced data. Ap\&SS. 39(2), 447-462. https://doi.org/10.1007/BF00648343.

Lüdecke, H.J., Weiss, C.O., Hempelmann, M., 2015. Paleoclimate forcing by the solar De Vries/Suess cycle. Climate of the Past 11, 279-305. https://doi.org/10.5194/cpd-11-279-2015

Lüning S., Gałka M., Bamonte F. P., García-Rodríguez F., Vahrenholt F., 2018. The Medieval Climate Anomaly in South America. Quaternary International. https://doi.org/10.1016/j.quaint.2018.10.041

Mahiques, M.M., Wainer, I.K.C., Burone, L., Nagai, R., Sousa, S. H. M., Figueira, R.C.L., da Silveira, I.C.A., Bicego, M.C., Alves D.P.V., Hammer, O., 2009. A high-resolution Holocene record on the Southern Brazilian shelf: Paleoenvironmental implications. Quaternary International 206, 52-61. https://doi.org/10.1016/j.quaint.2008.09.010

Mahowald, N.M., Muhs, D.R., Levis, S., Rasch, P.J., Yoshioka, M., Zender, C.S., Luo, C., 2006. Change in atmospheric mineral aerosols in response to climate: Last glacial period, preindustrial, modern, and doubled carbon dioxide climates. Journal of Geophysical Research D: Atmospheres 111, D10202. https://doi.org/10.1029/2005JD006653

Marrero, A., Tudurí, A., Pérez, L., Cuña, C., Muniz, P., Lopes, Figueira, R.C., Mahiques, M. M., Pittauerová, D., Hanebuth, T., García-Rodríguez, F., 2014. Cambios históricos en el aporte terrígeno de la cuenca del Río de la Plata sobre la plataforma interna uruguaya. LAJSBA. 21(2), 165-179.

Martins, L.R., Martins, I.R., Urien, C.M., 2003. Aspectos sedimentares da plataforma continental na área de influencia de Rio de La Plata. Gravel 1, 68-80.

Martins, L.R., Urien, C.R., 2004. Areias da plataforma e a erosao costeira. Gravel 2,4-24.

Martins, V., Dubert, J., Jouanneau, J.-M., Weber, O., Ferreira da Silva, E., Patinha, C., Alverinho Dias, J.M., Rocha, F., 2007. A multyproxy approach of the Holocene evolution of shelf-slope circulation on the NW Iberian continental shelf. Marine Geology 239, 1-18. https://doi.org/10.1016/j.margeo.2006.11.001

Masello, A., Menafra, R., 1998. Macrobenthic comunities of the Uruguayan coastal zona and adjacent areas, in: Río de la Plata una revisión ambiental. In: Wells, P.G. and Daborn, G.R. (eds), University of Dalhousie, pp. 140-186.

Meyer, I., Wagner, I., 2009. The Little Ice Age in Southern South America: Proxy and model-based evidence. In: Vimeux F., Sylvestre F., Khodri M. (eds), Past climate variability in South 
America and surrounding regions, from the last glacial maximum to the Holocene. Springer, pp. 395-412.

Meyer-Jacob, C., Vogel, H., Boxberg, F., Rosén, P., Weber, M.E., Bindler, R., 2014. Independent measurement of biogenic silica in sediments by FTIR spectroscopy and PLS regression. Journal of Paleolimnology 52, 245-255. https://doi.org/10.1007/s10933-014-9791-5

Möller Jr., O.O., Piola, A.R., Freitas, A.C., Campos, E., 2008. The effects of river discharge and seasonal winds on the shelf off southeastern South America. Continental Shelf Research 28(13), 1603-1624. https://doi.org/10.1016/j.csr.2008.03.012

Moy, C.M., Moreno, P.I., Dunbar, R.B., Kaplan, M.R., Francois J.P., Villalba, R., Haberzettl, T., 2009. Climate change in SouthernSouthern South America during the last two millennia, in: Past climate variability in South America and surrounding regions. In: Vimeux, F., Sylvestre, F., Khodri, M., Developments in Paleoenvironmental Research 14, Springer, pp. 353-393.

Novello, F., Cruz, F.W., Karmann, I., Burns, S.J., Stríkis, N., Vuille, M., Cheng, H., Edwards, L., Santos, R.V., Frigo, E., Barreto, E.A.S., 2012. Multidecadal climate variability in Brazil's Nordeste during the last 3000 years based on speleothem isotope records. Geophysical Research Letters 39, L23706. https://doi.org/10.1029/2012GL053936.

Novello V. F., Vuille M., Cruz F. W., Stríkis N. M., De Paula M. S., Edwards R. L., 2016. Centennial-scale solar forcing of the South American Monsoon System recorded in stalagmites. Scientific Reports 6 (24762). https://doi.org/10.1038/srep24762.

Ólafsdóttir, K.B., Geirsdóttir, A., Miller, G.H., Larsen, D.J. 2013. Evolution of $\mathrm{NAO}$ and AMO strenght and cyclicity derived from a 3-Ka varve-thickness record from Iceland. Quaternary Science Reviews 69, 142-154. https://doi.org/10.1016/j.quascirev.2013.03.009

Patterson, R.T., Prokoph, A., Reinhardt, E., Roe, H.M., 2007. Climate cyclicity in late Holocene anoxic marine sediments from the Seymour-Belize Inlet complex, British Columbia. Marine Geology 24, 123-140. https://doi.org/10.1016/j.margeo.2007.04.003

Pausata, F.S.R., Chafika L., Caballero, R., Battisti, D.S., 2015. Impacts of high-latitude volcanic eruptions on ENSO and AMOC. PNAS 112(45), $13784-$ 13788. https://doi.org/10.1073/pnas.1509153112

Perez, L., García-Rodríguez, F., Hanebuth, T.J.J., 2017. Paleosalinity changes in the Río de la Plata estuary and on the adjacent Uruguayan continental shelf over the past $1200 \mathrm{cal} \mathrm{ka}$ BP: an approach using diatoms as proxy. In: Weckström, K. Saunders, P., Skilbeck, G. (eds), Applications of paleoenvironmental techniques in estuarine studies, Developments in Paleoenvironmental Research (DPER), Springer, pp. 529-550.

Perez, L., García-Rodríguez, F., Hanebuth, T.J.J., 2016. Variability in terrigenous sediment supply offshore of the Rio de la Plata (Uruguay) recording the continental climatic history over the past 1200 years. Climate of the Past 12, 623-634. https://doi.org/10.5194/cp-12-623-2016.

Petrovskii, S.K., Stepanova, O.G., Vorobyeva, S.S., Pogodaeva, T.V., Fedotov, A.P., 2016. The use of FTIR methods for rapid determination of contents of mineral and biogenic components in lake bottom sediments, based on studying of
RESEARCH PAPER

East Siberian lakes). Environmental Earth Sciences 75, 226. https:/ / doi.org/10.1007/s12665-015-4953-y

Piola, A.R., Matano, R.P., Palma, E.D., Moller, Jr.O.O., Campos E.J.D., 2005. The influence of the Plata River discharge on the western South Atlantic shelf. Geophysical Research Letters 32, L01603. https://doi.org/10.1029/2004GL021638.

Piola, A.R., Moller, O.O., Guerrero, R.A., Campos, E.J.D., 2008. Variability of the subtropical shelf front off eastern South America: Winter 2003 and summer 2004. Continental Shelf Research 28, 1639-1648. https://doi.org/10.1016/j.csr.2008.03.013.

Piovano, E.L., Ariztegui, D., Cordoba, F., Cioccale, M., Sylvestre, F., 2009. Hydrological variability in South America below the tropic of Capricorn (Pampas and Patagonia, Argentina) during the Last 13.0 Ka. In: Vimeux, F, Sylvestre, F, Khodri, M (eds), Past climate variability in South America and surrounding regions, from the last glacial maximum to the Holocene, Springer, pp. 323-352.

Robertson, A.W., Mechoso, C.R., 2000. Interannual and interdecadal variability of the South Atlantic Convergence Zone. Monthly Weather Review 128, 2947-2957. https://doi.org/10.1175/1520-0493(2000)128<2947:IAIVOT>2.0.CO;2

Robertson, A.W., Mechoso, C.R., 1998. Interannual and Decadal Cycles in River Flows of Southeastern South America. Journal of Climate 11, 2579-2581. https://doi.org/110.1175/1520 0442(1998)011<2570:IADCIR > 2.0.CO;2

Salazar, A., Lizano, O.G., Alfaro, E.J., 2004. Composición de sedimentos en las zonas costeras de Costa Rica utilizando Fluorescencia de Rayos-X (FRX). Revista de Biología Tropical 52, 0034-7744.

Salvatteci, R., Gutiérrez, D., Field, D., Sifeddine, D., Ortlieb, L., Bouloubassi, I., Boussafir, M., Boucher, H., Cetin, F., 2014. The response of the Peruvian Upwelling Ecosystem to centennial-scale global change during the last two millennia. Climate of the Past 10, 715-731. https://doi.org/10.5194/cp10-715-2014

Scargle, J.D., 1982. Studies in astronomical time series analysis. II. Statistical aspects of spectral analysis of unevenly spaced data. The Astrophysical Journal 263(2), 835-853.

Scargle, J.D., 1989. Studies in astronomical times series analysis. III. Fourier transforms, autocorrelation functions, and crosscorrelation functions of unevenly spaced data. The Astrophysical Journal 343 (2), 874-887.

Seager, R., Naik, N., Baethgen, W., Robertson, A., Kushnir, Y., Nakamura, J., Jurburg, S., 2010. Tropical oceanic causes of interannual to multidecadal precipitation variability in Southeast South America over the past century. Journal of Climate 23, 5517-5539. https://doi.org/10.1175/2010JCLI3578.1

Schulz, M., Mudelsee, M., 2002. REDFIT: estimating red-noise spectra directly from unevenly spaced paleoclimatic time series. Computers \& Geosciences. 28, 421-426.

Torrence, C., Compo, G.P., 1998 A practical guide to wavelet analysis. BAMS 79, 61-78.

Vuille, M., Burns, S.J., Taylor, B.L., Cruz, F.W., Bird, B.W., Abbott, M.B., Kanner, L.C., Cheng, H., Novello, V.F., 2012. A review of the South American monsoon history as recorded in stable isotopic proxies over the past two millennia. Climate of the Past 8, 1309-1321. https://doi.org/10.5194/cp-8-13092012. 
Welch, P.D., 1967. The use of Fast Fourier Transform for the estimation of power spectra: A method based on time averaging over short, modified periodograms. IEEE Transactions on Audio and Electroacoustics. AU-15(2), 70-73, https://doi.org/10.1109/TAU.1967.1161901.

Weltje, G.J., Tjallingii, R., 2008. Calibration of XRF core scanners for quantitative geochemical logging of sediment cores: Theory and application. Earth Planetary Sciense Letters 274(3-4), 423438. https://doi.org/10.1016/j.epsl.2008.07.054, 2008
RESEARCH PAPER

Wold, S., Sjöström, M., Eriksson, L., 2001. PLS-regression: a basic tool of chemometrics. Chemometrics and Intelligent Laboratory Systems 58(2), 109-130.

Yarincik, K., Murray, M.R.W., Peterson, L.C., 2000. Climatically sensitive eolian and hemipelagic deposition in the Cariaco Basin, Venezuela, over the past 578000 years: Results from $\mathrm{Al} / \mathrm{Ti}$ and $\mathrm{K} / \mathrm{Al}$. Paleoceanography 15, 210-228. https://doi.org/10.1029/1999PA900048.

Zhou J., Lau, K.-M., 1998. Does a monsoon climate exist over South America? Journal of Climate 11, 1020-1040. bttps:/ / doi.ong/10.1175/1520-0442(1998)011<1020:DAMCEO>2.0.CO;2 